Masthead Logo

digitalcommons.nyls.edu

2009

Imagine All the Women: Power, Gender and the Transformative Possibilities of the South African Constitution

Penelope Andrews

Follow this and additional works at: https://digitalcommons.nyls.edu/fac_articles_chapters

Part of the Human Rights Law Commons, and the Law and Gender Commons 


\section{CHAPTER ELEVEN \\ IMAGINE ALL THE WOMEN \\ Power, Gender and the Transformative Possibilities of the South African Constitution}

Penelope E. Andrews

It is argued here that a creative jurisprudence of equality coupled with substantive interpretation of the content of 'socio-economic' rights should restore social justice as a premier foundational value of our constitutional democracy side by side, if not interactively with, human dignity, equality, freedom, accountability, responsiveness and openness. ${ }^{\prime}$

\section{Introduction}

This chapter will explore the South African Constitution, and more particularly, the Bill of Rights, as a vehicle for social and economic transformation. By analyzing the provisions relating to gender equality in South Africa's Constitution, as well as decisions of the Constitutional Court, this chapter will examine whether the constitutional rights framework in South Africa contains within it the transformative possibilities ${ }^{2}$ that will lead to gender equality in all spheres of South African society, and particularly in the economic sphere. Karl Klare refers to transformative constitutionalism as

a long-term project of constitutional enactment, interpretation, and enforcement committed (not in isolation, of course, but in a historical context of conducive political developments) to transforming a country's political and social institutions and power relationships in a democratic, participatory, and egalitarian direction.",

This chapter's focus on women as a group should not be seen as detracting from the contemporary social reality, where the condition of poverty affects a large number of South Africans of all genders. ${ }^{4}$ However, black women continue to be disproportionately represented in all negative indicators, including poverty, rates of unemployment, and occurrence of AIDS. The analysis in this chapter proceeds on the belief that women's 
access to resources and women's economic empowerment is integrally linked to the legal, political and social conditions that create the possibilities for such access and empowerment. Sandra Liebenberg explains the transformative potential of the South African constitutional framework:

Unlike many classic liberal constitutions, its primary concern is not to restrain State power, but to facilitate a fundamental change in unjust political, economic and social relations in South Africa. ${ }^{5}$

In line with this theme of transformation, and attempting to provide a comprehensive approach to gender equality, the analysis in this chapter not only references the constitutional text and constitutional jurisprudence that focus on socio-economic rights, but also engages with constitutional text and decisions that articulate a vision of equality, a constitutional proscription of violence against women, and cultural impediments that may thwart the quest for gender equality.

\section{Constitutionalism and Socio-Economic Rights}

In South Africa's evolving constitutional democracy, constitutional adjudication is a central component of the basic governance structure. Such a framework, at least symbolically, signifies that the needs and interests of the poor are a matter of national public concern. In addition, such a framework raises the possibility of removing the socio-economic barriers to full citizenship. ${ }^{6}$ The inclusion of social and economic rights in the constitution therefore converts the issue of the needs of the poor into the realm of legal entitlement. As the South African scholar Daniel Brand notes:

First, courts' adjudication of socio-economic rights claims becomes part of the political discourse, even a medium through which this discourse partly plays out. Second, courts also occupy a symbolic, or perhaps more accurately, an exemplary, role with respect to poverty and need discourses - their vocabulary, the conceptual structures they rely on, the rhetorical strategies they employ infiltrate and so influence and shape the political discourses around poverty and need. ${ }^{7}$

Although Karl Klare has cautioned that the "decision" to "accomplish some significant portion" of the law-making process "through adjudication" is one "fraught with institutional consequences," litigating in the pursuit of socio-economic rights opens up great possibilities for women. For women, especially black women, the Constitution's 
incorporation of a host of socio-economic rights, and particularly its transformative potential, as outlined above, is an important antidote to the axis of gender subordination: namely, poverty, violence and custom. ${ }^{9}$

This chapter is limited in scope. Although it highlights the powerful symbolic and substantive possibilities of the constitutionalizing of socioeconomic rights and rendering such rights fully justiciable, it does not address key economic questions that are central to reducing poverty. ${ }^{10}$ In addition, it highlights merely one aspect of the relationship between law and economic development, namely, the possibilities generated by the constitutional enforcement of rights. ${ }^{11}$ The prevalence of poverty, as a recurring reality of the majority of Africa's population, including South Africa, continues to be an issue of global concern that has taxed the creativity of a range of scholars. ${ }^{12}$

There is a vast body of literature pointing to the limitations of rights discourse in the face of economic structures that reinforce economic inequality. ${ }^{13}$ Legal scholars such as Upendra Baxi and Boa de Sousa Santos have eloquently argued that the language of human rights has in effect replaced the language of economic redistribution and thereby has appropriated other ethical discourses. ${ }^{14}$ Indeed, the seductive possibilities generated by litigation for social and economic rights may disproportionately influence communities, especially women, to redirect their attention from non-legal transformative strategies that may produce a deeper and more enduring economic, political and social justice. ${ }^{15}$ This debate is a vigorous one within the contemporary human rights community of scholars and advocates, and is also a hackneyed one reminiscent of the earlier civil rights struggle of the United States. ${ }^{16}$

By integrating the questions of women's economic empowerment within the context of violence against women and customs that impede women's equality, I am influenced by the critical voices of legal scholars who insist on a comprehensive intersectional approach to rights. I am in particular referring to the scholarship of Angela Harris and Taunya Banks, who exhort us to eschew essentialism in theorizing women's subordination. ${ }^{17}$ In addition, Amanda Gouws has attempted in her work to deconstruct the gendered nature of South African citizenship in its many guises. ${ }^{18}$ The approach of the South African Bill of Rights, namely, an expanded notion of equality, distinguishes it from many other constitutional projects, notably that of the United States. In South Africa, constitutional adjudication occurs in a context that recognizes that disadvantage and discrimination are deeply embedded in the political, economic and legal systems, and that the legacy of apartheid and sexism will continue into the foreseeable future. ${ }^{19}$ The constitutional text and its 
interpretation are therefore predicated on a need to derogate purposively from the status quo. As the first President of the Constitutional Court has noted:

We live in a society in which there are great disparities in wealth. Millions of people are living in deplorable conditions and in great poverty. There is a high level of unemployment, inadequate social security, and many do not have access to clean water or to adequate health services. These conditions already existed when the Constitution was adopted, and a commitment to address them, and to transform our society into one in which there will be human dignity, freedom and equality, lies at the heart of our new constitutional order. ${ }^{20}$

In other words, both text and interpretation are mandated to transform social and economic relations. ${ }^{21}$

\section{Rights Protected in the South African Constitution}

The South African Constitution, in particular the Bill of Rights, has been universally heralded as one of the most impressive human rights documents of the twentieth century. ${ }^{22}$ Section 1 states very clearly the supremacy of the Constitution, and also states that the new democratic state is founded on values that include "human dignity and the achievement of equality" as well as "non-racialism and non-sexism." The Constitution's generous coverage of a broad range of categories of discrimination, including race, gender, sexual orientation, and national origin, seeks to reassure all South Africans that discrimination in its obvious, as well as intricate variations, will not be tolerated. ${ }^{23}$

Covering both direct and indirect discrimination ${ }^{24}$ and recognition of the tenacity of institutionalized discrimination, the Bill of Rights also covers "intersectional discrimination," noting that "no person may unfairly discriminate directly or indirectly against anyone on one or more grounds. "25 Judge Goldstone, in an early gender equality case, noted the complex relationships among the prohibited grounds of discrimination, exhorting against the temptation to force them into neatly self-contained grounds. $^{26}$

This comprehensive definition of equality also embodies a clear commitment to affirmative action, which provides that:

To promote the achievement of equality, legislative and other measures designed to protect or advance persons, or categories of persons, disadvantaged by unfair discrimination may be taken. ${ }^{27}$ 
In addition, the Bill of Rights outlaws violence against women in both the public and private sphere, ${ }^{28}$ as well as protecting a woman's right to "bodily" and psychological integrity," including the "right to make decisions concerning reproduction." 29 The Bill of Rights also protects freedom of expression given that it does not involve advocacy of hatred based on race, ethnicity, gender or religion, and that it does not constitute incitement to cause harm. ${ }^{30}$

But the incorporation of socio-economic rights arguably holds the key to unraveling much of the subordination and disadvantage that disproportionately burden women. Most particularly, these rights that incorporate education, ${ }^{31}$ housing, ${ }^{32}$ health care, food, water and social security, ${ }^{33}$ provide, at least within the formal legal paradigm, a limited access for women to pursue some form of economic empowerment.

The rights of children are comprehensively embraced, especially as they relate to their social and economic well-being. Children are therefore given the right to "basic nutrition, shelter, basic health care services and social services." 34 Children are also protected from "maltreatment, neglect, abuse or degradation" 35 and "exploitative labor practices." These rights are provided on demand, and the provision does not include the limitation found in other socio-economic rights in the Bill of Rights, namely, that the state provide them progressively and "within its available resources."

Although the Constitution is clear about the rights of cultural, religious or linguistic communities to "enjoy their culture, practice their religion and use their language," ${ }^{, 37}$ they cannot do so if those practices violate the principle of equality. This provides women in those distinct communities significant protections, ensuring that their membership in their discrete communities is not compromised by their being relegated to a second-class status. The Constitution embodies several bodies to promote the rights in the Bill of Rights, including the Human Rights Commission and the Commission for Gender Equality. ${ }^{38}$

\section{The Constitutional Court's Rights Interpretation}

Since its establishment in 1995, the Constitutional Court has had occasion to consider the application and interpretation of equality, particularly gender equality, and has for the most part articulated a definition of equality that considers comprehensively the many ways that South African women experience discrimination and disadvantage. The Court has elaborated at length what equality means, and in its several judgments has applied the equality principle in a manner that is mindful of the context in which the discrimination occurs, and the lived reality of the parties under consideration. In addition, the Court has focused on the goal 
of the Constitution, namely, the achievement of dignity and equality for all South Africans. The Court has therefore embraced a substantive definition of equality, as opposed to a mere formalistic one, in effect focusing on the disparate impact of laws, policies and practices, as opposed to their strict equal treatment of the genders. ${ }^{39}$

One of the first cases on gender equality involved an unmarried father who challenged the provisions of the Child Care Act, which permitted the adoption of children born out of wedlock without the consent of the father. ${ }^{40}$ For children born in wedlock, the consent of both parents was required. The father successfully challenged the law and it was declared unconstitutional. In evaluating the Child Care Act, and particularly the gender equality issues raised in this case, the late Justice Mahomed noted:

In considering appropriate legislative alternatives, parliament should be acutely sensitive to the deep disadvantage experienced by single mothers in our society. Any legislative initiative should not exacerbate that disadvantage. ${ }^{41}$

Adopting a contextual approach, the Court stated that a mother's "biological relationship with the child," nurtured during pregnancy and breastfeeding, is a special one. ${ }^{42}$ The Court also noted that the mother gives "succor and support" to a child that is "very direct and not comparable to that of a father." several systems of marriage in South Africa, including some that were not formal. $^{44}$ Children who were products of such informal unions were rendered illegitimate, therefore disposing of the father's permission for adoption. Such situations of non-recognition placed fathers at an enormous disadvantage vis a vis their children with respect to adoption, and were therefore discriminatory. In addition, the Court also considered that the core issue was really the relationship between a father and a child, and that the statute was too broad in its blanket exclusion of the need for an unmarried father's permission for adoption of his child. The Constitutional Court, however, citing the best interest of the child, declined to allow further appeal to set aside the adoption, but instructed Parliament to remedy the situation in a revised statute.

The second case, one in which the Court's analysis provides a lengthy blueprint for the approach to equality in South Africa, has been fairly controversial. In this case the applicant, a convicted prisoner, challenged a Presidential pardon that pardoned certain categories of prisoners, including women in prison, who had children under the age of twelve at the time of South Africa's first election. ${ }^{45}$ 
Hugo challenged the Presidential pardon on the basis that it violated his constitutional rights to equality and that it discriminated against him on the basis of gender. The Court, in its judgment, went through an elaborate discussion of equality. It then applied the two-pronged test outlined in the Constitution, namely, that if discrimination is alleged and found on any of the particular grounds, such as race, gender, and marital status, that finding creates a presumption of unfairness. ${ }^{46}$ The person against whom the allegation of discrimination is made must then rebut the presumption of unfairness by showing the validity of the action. The Court, in its analysis, looked at the Presidential pardon and found it to be unfair; the need for the President to rebut the presumption arose. The Court examined the reasons for the Presidential pardon, including an evaluation of those who would benefit from the pardon. These included children whose mothers or fathers were in prison.

The Court then examined the other group who benefited from the pardon, namely,

women, the most disadvantaged group in South African society. The Court acknowledged that mothers are the primary caregivers of children, but it also recognized that this reinforced a stereotype about women, childcaring, and child-rearing. Despite this, Justice O'Regan noted:

To determine whether the discrimination is unfair it is necessary to recognize that although the long-term goal of our constitutional order is equal treatment, insisting upon equal treatment in all circumstances of established inequality may well result in the entrenchment of that inequality. ${ }^{47}$

The Court adopted a pragmatic approach and tried to place the issue in the South African context. Observing that women have historically been discriminated against, the Court's approach to equality will likely benefit but it will not perpetuate a disadvantage.

In this case, mothers have been afforded an advantage on the basis of a proposition that is generally speaking true. There is no doubt that the goal of equality entrenched in our constitution would be better served if the responsibilities of child-rearing were more fairly shared between fathers and mothers. The simple fact is that at present they are not. ${ }^{48}$

Disputing that women are put at a disadvantage when they are perceived as the primary caregivers of children, Justice O'Regan noted further:

The profound disadvantage lies not in the President's statement, but in the social fact of the role played by mothers in child-rearing and, more 
particularly, in the inequality which results from it. There can be no doubt that where reliance upon the generalization results in greater disadvantage for mothers, it would almost without question constitute unfair discrimination. ${ }^{49}$

The dissent forcefully challenged the stereotypes the majority opinion appeared to perpetuate, stating that the Constitution is meant to be transformative. Part of that transformative vision is not to reinforce old stereotypes, but to pursue a vision in which, in this case, fathers are also seen as caregivers of children. The dissent objected strongly to the pragmatic approach that the majority took. Justice Kriegler insisted that where some rebuttal is provided for the presumption of unfairness, such rebuttal must be scrutinized thoroughly and must not be "discharged with relative ease." ${ }^{50} \mathrm{He}$ took issue with the rationale that women were the primary caregivers of young children, stating this generalization to be

a root cause of women's inequality in our society. It is both a result and a cause of prejudice: a societal attitude which relegates women to a subservient, occupationally inferior yet unceasingly onerous role. It is a relic and feature of the patriarchy which the Constitution so vehemently condemns. $^{51}$

The majority had considered an alternative, that is, to release fathers of children under the age of twelve, but in assessing this alternative, noted first that there are significantly larger numbers of male prisoners in South Africa than female prisoners, so the numbers of men who would be released would be enormous. Second, the Court recognized the serious problem of crime in South Africa and the public outcry that would follow a large release of male prisoners. The dissenting opinion voiced its alarm at the stereotypes that were reinforced in the majority's judgment. ${ }^{52}$ The Hugo decision, although controversial, has been praised in many quarters for specifically contextualizing women's oppression and the discrimination that women suffer in South Africa. But the Court has had difficulty coming to grips with a vision or articulation of equality that some commentators have argued is inconsistent. ${ }^{53}$

The Court has expanded its vision on equality to examine the impact of violence on women's equality. In 2000 the Constitutional Court confronted a challenge to the constitutionality of a provision in the Prevention of Family Violence Act which, it was argued, reversed the onus of proof in domestic violence matters and thus violated the right of an accused person to be presumed innocent. ${ }^{54}$ The issue arose out of the conviction of the appellant in the lower court for breaking an interdict issued by the court asking him not to assault his wife or prevent her or 
other clients from entering or leaving their homes. He was found guilty under the Prevention of Family Violence Act of 1993. He argued that the section under which he was arrested was unconstitutional to the extent that it placed an onus on him to prove no guilt. Justice Sachs, writing for the majority in a unanimous decision, embarked on a thoughtful analysis of the need to deal comprehensively and effectively with the problem of domestic violence. He described the "hidden, repetitive character" of domestic violence, its ubiquity in cutting across class, race, culture and geographic boundaries, and the deleterious consequences for society of its persistence. He characterized domestic violence as a matter of gender equality, noting that because of the gender-specific nature of domestic violence, it mirrored patriarchal domination in a particularly abhorrent manner. In proceeding to analyze the conflicting rights at stake, the Court found that the presumption of innocence had not been disturbed because there were other mechanisms in place to ensure an "accessible, speedy, simple and effective" process.

This judgment follows the Hugo and Fraser decisions in contextualizing the contemporary reality of South African women. In South Africa widespread violence against women in both the public and private sphere is a cause for great concern. Indeed, some would argue that such violence constitutes a continual violation of women's human rights. ${ }^{55}$ Justice Sachs, writing for the majority, forcefully acknowledges the need to eradicate such violence without constraining the constitutional rights of the perpetrators.

Feminist advocates and human rights advocates have argued that private violence, indeed any violence, against women is odious, and that the state ought to deal with this problem aggressively. Although the Baloyi decision gives some succor to victims of domestic violence, there is still some dissonance between certain cultural attitudes, fueled by a particular brand of South African masculinity that gives rise to such violence, and the laudable statements of the Court. ${ }^{56}$ Closing this gap will require a recognition that the structural and attitudinal impediments to the "right to be free from private violence" ${ }^{\text {} 57}$ as articulated in the Bill of Rights can only be eradicated by a combination of governmental assaults which include education, access to resources, and continued vigilance regarding the extent and persistence of violence. The Constitutional Court, at least, is doing its part, but it needs to be bolstered by other institutional arrangements that will include both legal and extra-legal measures.

It is with respect to the implementation of socio-economic rights that the Constitution holds much promise. The Constitutional Court's decisions regarding the enforcement of socio-economic rights has shown that these 
rights can bring meaningful relief to the poorest in the country. In 2000 the Constitutional Court had to consider the right to housing as incorporated in Section $26 .^{58}$ Although the Court had had occasion to interpret the right to health a few years prior, ${ }^{59}$ the Grootboom decision was awaited with much anticipation and is widely regarded as an international test case on the enforceability of social and economic rights. ${ }^{60}$ The case concerned an application for temporary shelter brought by a group of people, including a number of children, who were without shelter following their brutal eviction from private land on which they were squatting. The conditions under which the community lived were deplorable; they had access to one tap and no sanitation facilities. The Court affirmed that the government had a duty in terms of Section 26 of the Constitution (the right to adequate housing) to adopt reasonable policy, legislative and budgetary measures to provide relief for people who have no access to land, no roof over their heads, and who are living in intolerable conditions. Justice Yacoob, writing for a unanimous court noted:

I am conscious that it is an extremely difficult task for the state to meet these obligations in the conditions that prevail in our country. This is recognized by the Constitution, which expressly provides that the state is not obliged to go beyond available resources or to realize these rights immediately. I stress however, that despite all these qualifications, these are rights, and the Constitution obliges the state to give effect to them. This is an obligation that courts can, and in appropriate circumstances, must enforce. $^{61}$

The judgment also dealt in detail with the implications of the children's socio-economic rights enshrined in the Bill of Rights.

Although this decision has been widely hailed as setting an important precedent for the enforcement of socio-economic rights at both the local and global level, many commentators have expressed disappointment in the Court's focus on "reasonableness." They instead argue that the Court should have applied the "minimum core approach" as adopted in the interpretation of the International Covenant on Economic, Social and Cultural Rights. ${ }^{62}$

In The Treatment Action case, ${ }^{63}$ the appeal to the Constitutional Court was directed at reversing orders made in a high court against the government because of perceived shortcomings in its response to an aspect of the HIV/AIDS challenge. The court found that the government had not reasonably addressed the need to reduce the risk of HIV-positive mothers' transmitting the disease to their babies at birth. More specifically, the finding was that government had acted unreasonably in (a) refusing to 
make an anti-retroviral drug called nevirapine available in the public health sector where the attending doctor considered it medically indicated, and in (b) not setting out a time frame for a national program to prevent mother-to-child transmission of HIV.

In addition to focusing on the positive aspects of socio-economic rights, that is, the obligation of the state to provide certain rights, the Court has also focused on what has been seen as the negative component of socio-economic rights. In a case involving the protection of a tenant against eviction in the process of executing a judgment on debts, the Court held that such a process violated the constitutional right to housing. ${ }^{64}$

In another landmark judgment in $2001,{ }^{65}$ and one which has profound ramifications for development of the common law, the Constitutional Court considered a claim by a woman who had been attacked and seriously injured by a man who was at the time awaiting trial for rape. In spite of a previous conviction for indecent assault and a history of violent behavior towards women, he had been released unconditionally on his own recognizance in the rape matter-despite repeated requests by the victim and other members of the community to keep the assailant in custody. The victim sued the police and prosecution for their negligent failure to take proactive steps to protect her as a potential further victim. A unanimous court stated that the Constitution embodies an objective, normative value system that must shape the common law. The Constitution obliged the state to respect, protect, promote and fulfill the rights in the Bill of Rights, including the right of women to have their safety and security protected. The Constitutional Court found in her favor, namely, that the state officials had a legal duty to take steps to prevent further violent actions by the perpetrator, and referred the matter back to the trial court for determination of further issues in the tort claim. At the later trial the Cape High Court found for the plaintiff and ruled that the state was indeed liable.

In one of the most remarkable judgments of the Constitutional Court, one that has tremendous potential in redressing the structural disadvantages that women experience under customary law, the Court in a detailed and far-reaching judgment struck down the customary African legal principle of primogeniture as it applies to the law of succession, which prevented female children from inheriting when their father died intestate. $^{66}$ The applicants in the cases were two minor daughters of the deceased and the sister of an unmarried brother. They had been denied the right to be declared heirs; male relatives instead stood to inherit the property of the deceased. What was particularly significant about the cases was the involvement of the Women's Legal Center, a women's legal 
advocacy organization in Cape Town that conducted a major campaign around the issues raised by the case. ${ }^{67}$

\section{Possibilities and Limitations of the Constitutional Pursuit of Socio-Economic Rights}

An examination of post-apartheid developments reveals that the narrative of the trajectory of gender equality in South African embodies profound contradictions. On the one hand, South Africa ranks as one of the top democracies in the world with respect to women's representation in Parliament, including an impressive number of Ministers, DeputyMinisters, and parliamentarians. The speaker of Parliament is a woman, and several females hold top ambassadorial posts. ${ }^{68}$

These impressive statistics exist alongside the alarming reality of severe poverty amongst women and children, and the shocking reality of violence against women. Indeed, all research indicators suggest that widespread rape and domestic violence against women has reached epidemic proportions. ${ }^{69}$ This apparent contradiction between impressive statistics regarding female involvement in the formal political systemparticularly in national governance - on the one hand, and widespread poverty and systemic violence against women on the other, raises troubling questions. This chapter therefore argues that violence against women and its cultural underpinnings are an obstacle to economic development overall, and specifically to the capacity of women to enjoy the benefits promised in the constitutional framework. ${ }^{70}$ Moreover, despite solid steps taken by the South African government to improve the plight of women, including the provision of housing and improved access to education and other social and economic benefits, aggressive governmental intervention is imperative in reversing the legacy of apartheid and its disproportionate impact on black women. The gap between the expansive provisions in South Africa's Constitution and the underlying reality of the lives of the majority of South Africa's women raises troubling questions regarding the possibilities of legal change in the face of extra-legal structural impediments to women's equality. At its most basic, this gap raises the question about how a country with such an admirable Constitution and Bill of Rights - with equality at the corecould elude the majority of women its promises and possibilities. ${ }^{71}$

This question is even more perplexing in light of a decade of extraordinary equality jurisprudence generated by the Constitutional Court, as outlined above, in which the judges eschew a formal equality for a more substantive version. The Court has committed itself, if not always 
successfully, to a transformative vision that centers on women's equality and the right to dignity. ${ }^{72}$ In addition, even though the interpretation of socio-èconomic rights by the Court has for the most part been of limited effect, the Court has provided an overarching framework that allows some possibilities for creative legal advocacy, in conjunction with other nonlegal methods of advocacy, to address women's poverty.

The answer to the question, obviously a complex one, may be located in the realm of the particular version of masculinity, a by-product of colonialism and apartheid. This masculinity, embodying indigenous and Western forms of patriarchy, persists despite the constitutional commitment to equality. ${ }^{73}$ This dilemma is not peculiar to South Africa, for South Africa is in many ways also a microcosm of other societies, particularly those in the developing world that confront tensions, conflicts and ambiguities in pursuing rights for women. These contradictions also are present in affluent societies, but the reality of pervasive poverty and weak state institutions bedevils the quest for equality in poorer countries. South Africa's ongoing attempts to pursue rights for women therefore are constantly challenged, and often compromised, by this masculinist ethos that constitutional guarantees can only erode so far.

In addition to the conditions of severe economic inequalities and the disturbing patterns of private and public violence against women, as mentioned above, the HIV/AIDS epidemic and its collateral consequences severely impede the quest for women's equality. Many rights are compromised by women's inability to access economic resources. For example, it is extremely difficult for women still caught in a cycle of economic dependency and powerlessness to prevent HIV infection or to gain access to treatment for AIDS. The core issue, really, is how a society is to internalize the formal legal framework that promises gender equality and translate it into a human rights culture.

\section{Conclusion}

In the final analysis, the existence of an expansive constitution is only a precondition for legal and other changes. Scholars and advocates have noted that despite laudable efforts by women's groups to incorporate women's rights into the democratic legal framework, including urging the government to pursue a gendered legislative agenda, much work still needs to be done. The constitutional and legal foundations have provided a framework for some possibilities to transform, or at least alter, women's lives for the better. ${ }^{74}$ However, the privatized nature of the South African economy and the imperatives of a market-driven agenda may undermine the transformative possibilities of the Constitution. It is widely recognized 
that women suffer disproportionately from the failure of government to provide adequately for health, education, social welfare services, and the other needs of the population, just like women suffer disproportionately when government cutbacks occur. The South African constitutional paradigm has not provided a vehicle to fundamentally challenge the South African government's economic policies. The Court has merely ensured that government policy takes account of its constitutional mandate. Consequently, the Constitution cannot comprehensively overturn the deep structural inequalities that face women in South Africa today; it may, however, force the powers that be not to ignore these inequalities.

Regarding gender equality, at most, the South African constitutional framework may demonstrate that a comprehensive constitutional and legal framework is necessary. But it also highlights that a constitutional and legal framework must be bolstered by an overarching vision that seeks to transform institutions, laws and practices that subjugate women. In addition, it must be supplanted by a cultural shift across all sectors of society - a shift that takes on board comprehensively the need to eradicate gender inequality in the social, political and economic spheres.

\section{Notes}

${ }^{1}$ D. Moseneke, "Transformative Adjudication," South African Journal of Human Rights 309, 314 (2002).

${ }^{2}$ Karl Klare, "Legal Culture and Transformative Constitutionalism," South African Journal of Human Rights 146 (1998).

${ }^{3}$ Ibid, 150.

${ }^{4}$ See Sixth Economic and Social Rights Report, South African Human Rights Commission (2006) at http://www.sahrc.org.za/sahrc_cms/publish/article_215.html.

${ }^{5}$ Sandra Liebenberg, "Needs, Rights and Social Transformation: Adjudicating Social Rights," Center For Human Rights And Global Justice Working Paper, Economic And Social Rights Series, Number 8, 2005.

${ }^{6}$ Penelope E. Andrews, "The South African Constitution as a Mechanism for Redressing Poverty," in Democratic Reform in Africa: Its Impact on Governance \& Poverty Alleviation (Muna Ndulo, ed. 2006) 57.

${ }^{7}$ D. Brand, "The Politics of Need Interpretation and the Adjudication of SocioEconomic Rights Claims in South Africa," in Theories Of Social And Economic Justice (A.J. Van der Walt ed. 2005) 17, 24.

${ }^{8}$ Karl Klare, Legal Culture and Transformative Constitutionalism, supra note 3 at 147.

"I am using the term "custom" very loosely here. It refers to the range of cultural practices and norms that underpin attitudes that embrace notions of female inferiority. 
${ }^{10}$ So it does not, for example, engage with the South African government's economic policies, or the manner in which resource allocation is determined by the South African state. For an interesting exploration of these economic issues, see Nicoli Nattrass And Jeremy Seekings, Class Race and Inequality in South Africa (2005).

${ }^{11}$ See Penelope E. Andrews, The South African Constitution as a Vehicle for Redressing Poverty, supra note 6. See also Murray Wesson, "Grootboom and Beyond: Reassessing Socio-Economic Jurisprudence of the South African Constitutional Court," 20 South African Journal on Human Rights 284 (2004).

12 See, for example, Paul Collier, The Bottom Billion: Why The Poorest Countries Are Failing And What To Do About It (2007); Jeffrey D. Sachs, The End Of Poverty (2006) And William Easterly, The White Man's Burden (2006).

${ }^{13}$ See, for example, Amartya Sen, Development As Freedom (1999); Makau wa Mutua, "The Ideology of Human Rights," 36, Virginia Journal Of International Law 589 (1996); Philip Alston, "The Myopia of the Handmaidens: International Lawyers and Globalization," 8 European Journal Of International Law 435 (1998); and Andy McKay and Polly Vizard, Human Rights And Poverty Reduction (March 2005) at http://www.odi.org.uk/publications $\wedge$ briefing.html\#books.

${ }^{14}$ Upendra Baxi, "Voices of Suffering and the Future of Human Rights," 8 Transnational Law \& Contemporary Problems 125, 147 (1998); Boaventura De Sousa Santos, Toward A New Common Sense: Law Science And Politics In The Paradigmatic Transition 266-67 (1995).

${ }^{15}$ See Bharati Sadasivam, "The Impact of Structural Adjustment on Women: A Governance and Human Rights Agenda," 19 Human Rights Quarterly 630 (1997); see also Economic Justice And Women's Rights, (Madre), at http://www.madre. org/articles/into/b10/ econjustice.html.

${ }^{16}$ See Thomas E. Jackson, From Civil Rights To Human Rights (2006).

17 See Taunya Lovell Banks, "Toward A Global Critical Feminist Vision: Domestic Work and the Nanny Tax Debate," 3 Journal of Gender, Race and Justice 1 (1999); and Angela P. Harris, "Race and Essentialism in Feminist Legal Theory," 42 Stanford Law Review 581 (1990).

${ }^{18}$ See Unlinking Citizenship (Amanda Gouws ed. 2005).

${ }^{19}$ Government of South Africa and others $v$ Grootboom and others 2001 (1) Sa 46 Paragraph 25.

${ }^{20}$ Soobramoney $v$ Minister of Health, KwaZulu-Natal 1998 (1) SA 765 (CC) at Paragraph 8.

${ }^{21}$ It is worth noting here that the South African Constitution mandates the South African Human Rights Commission to pursue the enforcement of social and economic rights through education, lobbying and monitoring of human rights. Specifically, Section 184 mandates that the South African Human Rights Commission promote respect for human rights and a culture of human rights; promote the protection, development and attainment of human rights; and monitor and assess the observance of human rights. This section also empowers the Commission to investigate and to report on the assessment of human rights; to educate, carry out research and to redress human rights violations. 
22 See, for example, Craig Scott and Phillip Alston, "Adjudicating Constitutional Priorities in a Transnational Context: A Comment on Soobramoney's Legacy and Grootboom's Promise," 16 South African Journal on Human Rights 206 (2000).

${ }^{23}$ Constitution of the Republic of South Africa (1996) [Consitution]. Section 9 (3) provides that: The state may not unfairly discriminate directly or indirectly against anyone on one or more grounds, including race, gender, sex, pregnancy, marital status, ethnic or social origin, color, sexual orientation, age, disability, religion, conscience, belief, culture, language and birth.

${ }^{24}$ Ibid.

${ }^{25} \mathrm{Ibid}$. Section 9 (4) (Emphasis added).

${ }^{26}$ President of the Republic Of South Africa v Hugo (1997) (6) BCLR 708 (CC). For a comprehensive discussion on the intersection of race and gender, see Penelope E. Andrews, "Human Rights, Globalization and Critical Race Feminism: Voices from the Margins," 3 Journal of Gender Race \& Justice 373 (2000); see also Adrien Wing \& Eunice Carvalho, "Black South African Women: Towards Equal Rights," 8 Harvard Human Rights Journal 8 (1995).

${ }^{27}$ Constitution, supra note 24, Section 9 (2).

${ }^{28} \mathrm{Ibid}$. Section 12 (1).

${ }^{29}$ Ibid. Section 12 (2).

${ }^{30}$ Ibid. Section 16 (2).

${ }^{31}$ Section 29 provides that: Everyone has the right

(a) to a basic education, including adult basic education; and

(b) to further education, which the state, through reasonable measures, must make progressively available and accessible. Ibid.

${ }^{32}$ Section 26 provides that:

1. Everyone has the right to have access to adequate housing.

2. The state must take reasonable legislative and other measures, within its available resources, to achieve the progressive realization of this right. Ibid.

${ }^{33}$ Section 27 provides that everyone has the right to have access to:

(a) health care services, including reproductive health care,

(b) sufficient food and water, and

(c) social security, including, if they are unable to support themselves and their dependants, appropriate social assistance. The state must take reasonable legislative and other measures, within its available resources, to achieve the progressive realization of this right. Ibid.

${ }^{34}$ Ibid. Section 28 (1) (c).

${ }^{35} \mathrm{Ibid}$. Section 28 (1) (d).

${ }^{36}$ Ibid. Section 28 (1) e). This section also provides that children have the right:

... not to be required or permitted to perform work or provide services that are (i) inappropriate for a person of that child's age; or (ii) place at 
risk the child's well-being, education, physical or mental health or - spiritual, moral or social development. Ibid. Section 28 (1) (f).

${ }^{37}$ Ibid. Section 31.

${ }^{38}$ Ibid. Section 181 (1). This section also includes the Public Protector and The Commission for the Promotion and Protection of the Rights of Cultural, Religious and Linguistic Communities.

${ }^{39}$ As Justice Goldstone noted in President of the Republic of South Africa v Hugo, supra note 27:

At heart of the prohibition of unfair discrimination lies a recognition that the purpose of our new constitutional ..... order is the establishment of a society in which all human beings will be accorded equal dignity and respect regardless of their membership of particular groups. Ibid at paragraph 41.

${ }^{40}$ Fraser $v$ The Children's Court, Pretoria North 1997 (2) BCLR 153 (CC)..

${ }^{41}$ Ibid. at Paragraph 44.

42 Ibid. Paragraph 25.

${ }^{43}$ Ibid.

${ }^{44}$ To address aspects of this problem, the South African government passed the Recognition of Customary Marriages Act in 1998.

${ }^{45}$ President of the Republic of South Africa v Hugo, supra note 27.

${ }^{46}$ Constitution, supra note 24 . Section 9 (5) states: Discrimination ... is unfair unless it is established that the discrimination is fair.

${ }^{47}$ President of the Republic of South Africa v Hugo, supra note 25 at Paragraph 112.

${ }^{48} \mathrm{Ibid}$ at Paragraph 113.

${ }^{49}$ Ibid.

${ }^{50}$ Ibid.

${ }^{51}$ Ibid.

52 Justice Kriegler concluded that a small number of women would benefit from the pardon, but the rebuttal and rationale for the rebuttal used by the majority would operate as a "detriment to all South African women who must continue to labour under the social view that their place is in the home." He concluded that the benefit to a few hundred women could not justify the continued stereotyping of women as the primary caregivers. Ibid.

53 Cathi Albertyn and Beth Goldblatt, "Facing the Challenge of Transformation: Difficulties in the Development of an Indigenous Jurisprudence of Equality," 14 South African Journal on Human Rights 248 (1998); see also D.M. Davis, "Equality: The Majesty of Legoland Jurisprudence," 116 South African Law Journal 398 (1999). It is interesting to note the expectation was that once the Constitutional Court was established, litigants coming before the Court would be the most disadvantaged sector of South African society, in light of the legacy of apartheid. This has not been the case. In the race discrimination area, the major 
cases have been brought by white litigants alleging race discrimination, or in one instance, a very wealthy black male. In the gender discrimination area, the litigants have for the most part been either males, or more affluent white females. This is not a problem of the Constitution per se, but rather raises questions about access to justice-a perennial one confronting societies burdened with severe economic inequalities between its citizens. Despite this, however, although the parties seeking relief and protection from the Constitutional Court have come from the ranks of the most disadvantaged in South Africa, one could argue that the Court has confronted the concerns of a large proportion of South Africa's disadvantaged populations, including women.

${ }^{54} S v$ Baloyi 2000 (1) BCLR 86 (CC).

55 See Rhonda Copelon, "Intimate Terror: Understanding Domestic Violence as Torture," in Human Rights of Women: National and International Perspectives (Rebecca Cook ed. 1994) 116.

${ }^{56}$ See Penelope E. Andrews, "Learning to Love After Learning to Harm: PostConflict Reconstruction, Gender Equality and Cultural Values," 15 Michigan State Journal of International Law 41 (2007).

${ }^{57}$ Supra note 29.

${ }^{58}$ Section 26 provides as follows: Everyone has the right to have access to adequate housing.

2) The state must take reasonable legislative and other measures, within its available resources, to achieve the progressive realization of this right. 3) No one may be evicted from their home, or have their home demolished, without an order of court made after considering all the relevant circumstances. No legislation may permit arbitrary evictions.

${ }^{59}$ Soobramoney $\mathrm{v}$ Minister of Health, supra note 21.

${ }^{60}$ Government of the Republic of South Africa v Grootboom 2000 (11) BCLR 1169.

${ }^{61}$ Ibid at paragraph 94.

62 Marius Pieterse, "Resuscitating Socio-Economic Rights: Constitutional Entitlement to Health Care Service," 22 South African Journal on Human Rights 473 (2006)

${ }^{63}$ Minister of Health and Others $v$ Treatment Action Campaign and Others 2002 (5) SA 721 (CC).

${ }^{64}$ Jaftha $v$ Schoeman and Others 2005 (1) BCLR 78 (CC). (CC).

${ }^{65}$ Carmichele v Minister of Safety and Security and Another 2001 (4) SA 938

${ }^{66}$ Bhe and Others $v$ Magistrate Khayelitsha and Others, CCT 49/03; Shibi v Sithole and Others, CCT 69/03; South African Human Rights Commission and Another $v$ President of the Republic of South Africa and Another, CCT 50/03.

${ }^{67}$ See http://www.wlce.co.za/cus_law_lit.php. 
${ }^{68}$ See Mavivi Manzini Mayakayaka, "Political Party-Quotas in South Africa," in The Implementation of Quotas: African Experiences (Julie Ballington ed. 2004), available at http://www.idea.int/loader.cfm?url=/commonspot/security/getfile.cfm \&pageid $=7841$.

${ }^{69}$ See Penelope E. Andrews, Learning to Love After Learning to Harm: PostConflict Reconstruction, Gender Equality and Cultural Values, supra note 55.

${ }^{70}$ Ibid.

${ }^{71}$ For a very interesting reflection on the challenges to addressing poverty as a constitutional imperative, see Lucy A. Williams, "Issues and Challenges in Addressing Poverty and Legal Rights: A Comparative United States/South African Analysis," 21 South African Journal on Human Rights 436 (2005).

${ }^{72}$ For a critique of the Constitutional Court's equality jurisprudence, see Cathi Albertyn and Beth Goldblatt, Facing the Challenge of Transformation: Difficulties in the Development of an Indigenous Jurisprudence of Equality, supra note 42. see also D.M. Davis, Equality: The Majesty of Legoland Jurisprudence, supra note 42.

${ }^{73}$ Indeed, Constitutional Court Justice Albie Sachs has referred to patriarchy as the "only truly non-racial institution in South Africa."

${ }^{74}$ The list of laws passed by the South African government to pursue equality for women include the Promotion of Equality and the Prevention of Unfair Discrimination Act, Act 4 of 2000 and the Domestic Violence Act, Act 116 of 1998. 